Article

\title{
"Sweden Has Been Naïve": Nationalism, Protectionism and Securitisation in Response to the Refugee Crisis of 2015
}

\author{
Mathias Ericson \\ Department of Cultural Sciences, Gothenburg University, 40530 Gothenburg, Sweden; E-Mail: mathias.ericson@gu.se
}

Submitted: 31 March 2018 | Accepted: 7 August 2018 | Published: 22 November 2018

\begin{abstract}
Fake news, disinformation campaigns, xenophobia, political resentment, and a general backlash on equality issues mark the current political climate. In this context, the idealism of the Swedish welfare state has gained a specific symbolic value. This article investigates how the idealisation of Sweden as a modern and gender-equal country was articulated as a focal point in the establishment of threat and crisis narratives in the political debate of the refugee crisis of 2015 . The article shows how progressive and egalitarian ideals were viewed as outdated and naïve, but at the same time put forward as core values worthy of protection. The title refers to the statement made by the Swedish Prime Minister in 2015 stating that "Sweden has been naïve" and serves as an example of how the myth of Sweden as an exceptionally modern, secular, and equal society was evoked in processes of securitisation, nationalistic protectionism, and normalisation of xenophobia. The article concludes that the articulation of Swedish exceptionalism in the establishment of threat and crisis narratives may reproduce and enhance social inequality and polarisation.
\end{abstract}

\section{Keywords}

gender; migration; neoliberalism; protectionism; refugee crisis; risk; securitisation; Sweden; welfare state

\section{Issue}

This article is part of the issue "Gender Equality and Beyond: At the Crossroads of Neoliberalism, Anti-Gender Movements, 'European' Values, and Normative Reiterations in the Nordic Model”, edited by Lena Martinsson (University of Gothenburg, Sweden), Diana Mulinari (Lund University, Sweden) and Katarina Giritli Nygren (Mid Sweden University, Sweden).

(C) 2018 by the author; licensee Cogitatio (Lisbon, Portugal). This article is licensed under a Creative Commons Attribution 4.0 International License (CC BY).

\section{Introduction}

The idealisation of Sweden as the most secure, modern, and gender-equal country in the world, expressed in the metaphor of "the people's home", is a powerful discourse (Martinsson, Griffin, \& Giritli Nygren, 2016). It works as a form of path-dependency (Cox, 2004) that limits national policies as well as influencing foreign policy, for instance, expressed in the current government's acclaimed feminist foreign policy. Critical studies have raised concerns about how the construction of a form of Swedish exceptionalism needs to be examined as a form of power struggle, calling attention to how it contributes to the silencing and normalisation of racist and gendered power asymmetries and excluding practices (de los Reyes, Molina, \& Mulinari, 2002; Habel, 2012; Martinsson et al., 2016; Schierup \& Ålund, 2011). In this article, I want to address how the idealisation of Sweden as secure, modern and gender-equal tends to gain a certain symbolic function in narratives of crisis. When Donald Trump stated "look what happened in Sweden", the idea of Swedish exceptionalism was used to evoke a sense of alarmism. This form of rhetoric is not unique to Trump but has also gained influence on the political discourses in Sweden. During the most dramatic events of the so-called "refugee crisis" in autumn 2015, liberal and right-wing politicians and commentators evoked the scenario that Sweden was facing a "system collapse" (Martinsson \& Reimers, 2017; Scarpa \& Schierup, 2018). The sense of collapse was dramatically charged with xenophobic discourses on migrant men sexually harassing women and supposedly being unable to adjust to the assumed gender-equal Swedish society (Rogberg, 2016; Stiernstedt, 2016). 
These forms of alarmism were reinforced and gained legitimacy in November 2015 after the Swedish government presented the dramatic decision to stop migrants at the border. The title of the article, that "Sweden has been naive", refers to the statement made by the Swedish Prime minister Stefan Löfven, leader of the Social Democrats, at a press conference due to the increased terrorist threat against Sweden on 19 November 2015 (Kärrman, 2015). The security police had just decided to raise the terrorism threat level and the Prime Minister argued that the security police had to be given an extended mandate of surveillance. The statement came just a week after the change in the Swedish refugee policy, which went from liberal to radically restrictive. At this specific press conference, it was stated that there were concerns that a terrorist had crossed the border into Sweden and that this fear must be taken seriously.

The aim of this article is to elaborate how the idealisation of Sweden as a modern and gender-equal country is articulated in current processes of securitisation. I am interested in how crisis situations provide opportunities to launch dramatic changes that may violate the very same ideals that it claims to be defending. The statement that "Sweden has been naïve" is considered as an example of how the myth of Sweden as an exceptionally modern, secular, and equal society is used to gain legitimacy for securitisation, nationalistic protectionism, and normalisation of xenophobia.

The article takes builds on ethnographic research (see Acknowledgements) carried out by professionals that work in the field of societal crisis preparedness and crisis management in public authorities in Sweden. This research focuses on how gendered norms inform crisis management, especially how masculinity constructions are reproduced and challenged through notions of protection and risk. It focuses on how professional expertise in this field is gendered and informs what area of risks is articulated as central reference objects in this kind of work (Ericson, 2017a, 2017b). The research has been carried out in relation to the last couple of years' dramatic events in Sweden in terms of terror attacks, wildfires, potential military conflicts, and the so-called refugee crisis of 2015. In this article, I want to specifically discuss the aspect of the refugee crisis in the political debate since this case stands out as a rather unsettling or silenced matter in interviews and observations. Migration could not as easily be used in making claims on protection and security in comparison with terror attacks, wildfires, or potential military conflicts. I became curious about why the dramatic events of 2015 were seldom mentioned in interviews and observations as a useful reference object. When mentioned, it rather served as an unsettling event that dramatically exposed the limited scope of crisis preparedness work (Ericson, 2017b). In this article, I will discuss this unsettling dimension, but also focus on how the refugee situation of 2015 influenced the political debate and how gender equality served as a focal point in the establishment of threat and crisis narratives in relation to this situation.
The article begins with a presentation of theoretical approaches to securitisation and masculinist protectionism, followed by two sections targeting how securitisation and masculinist protectionism influence the political debate on migration in Sweden. The first focuses on how threats to the gender-equal and secure Swedish society were established in relation to the changes in the Swedish government's migration policy in November 2015. The second focuses on how the imaginary defense of the gender-equal and secure Swedish society justified a form of necropolitics where some lives were rendered ungrievable. The article then ends with a section that draws out the article's main conclusions.

\section{Securitisation, Risk Management, and Neoliberalism}

Securitisation is a concept used and theorised in widely different fields of research (Balzacq, 2011). The process of securitisation is sometimes described as a specifically important political regime and as a new world order following the aftermath of the September 11 attacks (Agamben, 2005; Butler, 2004; Puar, 2007). However, theoretical works on the concept of securitisation and the societal processes that it designates go further back than this, not least the so-called Copenhagen School (Buzan, Wæver, \& de Wilde, 1998). As Neocleous states, it is also problematic to restrict securitisation to a new form of new world order since "the distinction between war and peace has always been blurred" and that the discourse on securitisation risks reproducing the liberal myth that "the state exists in order to realise this "liberal peace' within civil society" (Neocleous, 2010, p. 9).

In this article, I view securitisation as a concept that addresses specific elements of how power asymmetries gain legitimacy in neoliberal forms of governance, fostering a "political culture of danger" (Foucault, 2008, p. 66). Securitisation signifies how discourses of security gain hegemony in relation to, for instance, social policies or human rights. In The Administration of Fear, Paul Virilio states that:

States are tempted to create policies for the orchestration and management of fear. Globalisation has progressively eaten away at the traditional prerogatives of States (most notably the Welfare state), and they have to convince citizens that they ensure their physical safety. A dual health and security ideology have been established, and it represents a real threat to democracy. (Virilio, 2012, p. 15)

Securitisation would, from this perspective, suggest that neoliberalism does not simply hollow out the state through privatisation and marketization, but rather that "one of the few aspects of the capitalist state actually reinforced under neoliberalism is the security apparatus" (Neocleous, 2008, p. 159). Studies of the neoliberal reformation of public services, often referred to as New Public management, describe how government agencies are 
turning into various forms of "risk bureaucracies" (Hood, Rothstein, \& Baldwin, 2001) and that risk assessment has become a kind of universal remedy to recover the legitimacy of almost any organisation or sector (Power, 2004). Procedures of assessing and managing risk tend to obstruct and replace the core activities in many areas (Brown \& Calnan, 2010; Power, 1999; Rothstein, Huber, \& Gaskell, 2006).

As Methmann and Rothe (2012) describe, the political culture of danger rests on a somewhat paradoxical dynamic. The focus on security issues draws attention to politicians' and authorities' responsibilities and provides them with agency. At the same time, expectations are disclosed as unreasonable. "In the face of the apocalypse, politicians seem to be too small and 'human' to resolve the dawning crisis-hence, responsibility is handed over to the arcane and obscure practices and rationalities of risk management" (Methmann \& Rothe, 2012, p. 337). The inability to resolve the situation does not so much add up to a legitimacy crisis, but rather becomes a source of credibility in its own right. A similar paradox is described in Mirowski's (2013) work on the economic meltdown of 2008 in the US. Mirowski asks how it is possible that neoliberalism not only survived but even gained legitimacy. Although this crisis demonstrated the destructive forces of marketisation, it did not lead to a political debate on neoliberalism or risk orientation. Rather, marketisation and risk orientation were manifested as inevitable, only deepening the cult of neoliberal ideology. Mirowski suggests that confronting crisis and risks do not make the elephant in the room apparent, but may rather have the opposite effect. In a similar vein, I suggest that the seemingly paradoxical situation where a government presenting themselves as feminist launched conservative and masculinist forms of protectionism, may, in fact, be viewed as claiming political legitimacy.

\section{Masculinity and Protectionism}

The article relates to theoretical elaborations of the relation between securitisation and masculinity construction. It draws on the feminist critique of the state and security that stresses how protection works as a form of power relations permeated by masculinity construction. Security concerns articulate patriarchal logics where "a real man" is defined as the protector who must "suppress his own fears, brace himself and step forward to defend the weak, women and children" (Enloe, 1990, p. 12). As Stiehm points out, protection must be viewed as a relationship of power, where the protector may "control the lives of those he protects-in order to "better protect' them" (Stiehm, 1982, p. 372). These mechanisms are activated not only in states of war but also when society is confronted by terror attacks, crisis situations, and hazards (Butler, 2004; Gilson, 2014; Puar, 2007).

In her critique of the new security politics following the attacks of September 11, Young (2003) formu- lates a theory of masculinist protectionism drawing on Foucault's notion of pastoral power. She argues that, in the face of risk and looming threats, existing mechanisms provide legitimacy to paternalistic state powers and traditional patriarchal forms of masculinity. Young defines masculinist protectionism as a powerful discursive logic of distinguishing between those who can provide protection and those who are rendered passive and in need of protection. These positions are gendered, as providing protection is associated with masculinity while being vulnerable and unable to protect oneself is associated with femininity. It also rests on racist agendas, positioning white men as the "good" men that protect women from "bad" and "foreign" men. Young especially emphasises that the position of being vulnerable is circumscribed by a demand on being grateful and loyal to their protectors:

Public leaders invoke fear, then they promise to keep those living under them safe. Because we are afraid, and our fears are stirred by what we see on television or read in the newspaper, we are grateful to the leaders and officers who say that they will shoulder the risk in order to protect us. The logic of masculinist protection works to elevate the protector to a position of superior authority and to demote the rest of us to a position of grateful dependency. Ideals of democratic equality and accountability go by the wayside in the process. (Young, 2003, p. 13)

Following Young, it is possible to draw attention to the more subtle ways that masculinity is constructed in the process of mobilising resources, evoking agency and gaining legitimacy through claims on providing security. Another important aspect in relation to Young's (2003) elaboration of masculinist protectionism is the subject of vulnerability. Masculinist protectionism rests on the claim of being in a vulnerable state that must be reduced at any cost. For instance, Ahmed (2004) and Hochschild (2016) describe right-wing nationalist agendas to be legitimised by evoking and taking advantage of vague and diffuse feelings of a society or a nation vulnerable to harm. In terms of masculinity construction, it is also possible to, as Carroll states, "consider the various strategies by which white masculinity has transformed the universal into the particular as a means of restaging universality" (Carroll, 2011, p. 10). Masculinity is thus constructed not just by distance to vulnerability, since claims on being recognised as vulnerable may also be central to how masculinity is constructed in neoliberal times. This form of masculinity construction assumes a negative and reductionist view on vulnerability, considering it to be a dangerous and passive position that must be reduced in accordance with neoliberal ideals of the responsible, self-sufficient citizen (Gilson, 2014). Being able to seize and handle vulnerability could be considered as a central form of masculinist, heroic achievement that responds to and reproduces neoliberal ideals. 


\section{Staging Migration as a Security Problem}

The idealisation of Sweden as the most secure, modern, and gender-equal country in the world has been challenged over the last decades due to growing inequalities and social conflicts (Schierup \& Ålund, 2011). For instance, suburban riots and attacks on police and firefighters have gained recognition in international media as disturbing signs to the disarray of the Swedish welfare state (Ericson, 2014). In the current political debate, this destabilisation is frequently associated with migration, rather than the neoliberal social reforms of the past decades (Mulinari, 2016; Scarpa \& Schierup, 2018). This association was articulated in the autumn of 2015 as the number of migrants passing the borders of European nations increased dramatically. Despite previous reports of migrants drowning when attempting to cross the Mediterranean Sea, migration only gained a broader public recognition when increasing numbers of refugees reached the ferry-terminals and train stations in southern Sweden. Another important factor was the publication of the haunting image of the young boy Alan Kurdis's lifeless body washed up on the beach in Turkey on September 2 . By September 10, the national agency of crisis preparedness in Sweden, the Swedish Civil Contingency Agency (MSB), held a first national collaborative meeting of agencies, county boards, companies, and non-governmental organisations to address how the Swedish society was affected. From this point, MSB would hold a central position regarding the national management of the situation, supporting the involved actors, and collecting information presented to the government.

The alarming situation for the migrants brought about a massive manifestation of civilians, who provided clothes and food to migrants arriving at train stations in larger cities. Some support was organised but, in many cases, people's efforts where spontaneous and mobilised through Facebook, Twitter, and using Swish. At the beginning of these events, the government officially supported the civil society. When 15,000 people gathered in Stockholm at a manifestation under the banner "Refugees welcome", on September 6 2015, the Prime Minister held a speech asserting that Sweden would do everything in its power to assure that "Europe stands up for inviolable human dignity and rights" and that "we [the Swedes] will continue to be a country that carries solidarity as our greatest value" (Government Offices of Sweden, 2015a). However, two months later, the progress of the situation and the political conflicts within the EU forced the government to embark on a radically different path. By November 12, the Prime Minister from the Social Democrats and a minister from the coalition party, the Green Party, held a press conference to launch a dramatic change in Swedish policy regarding migration. Rather than openness and solidarity, it was claimed that the circumstances demanded Sweden to stop migrants at the border and adjust to the most restrictive migration policies possible within the EU.
The response to this decision was dramatic since it strongly challenged the spirit of being a nation that "carries solidarity as our greatest value". It also seemed to adjust to the alarmist rhetoric that had been repeated over the last couple of weeks by right-wing nationalist and conservative parties stressing that the "naïve" idealisation of solidarity would cause a "system collapse" (Berg, 2015; Martinsson \& Reimers, 2017; Scarpa \& Schierup, 2018). Although officials from MSB had previously stated that there was no substance in claiming that the society was facing "a system collapse" (MSB, 2015) the government has now stated that the dramatic decision was based on information provided not only by the security police, but also by the MSB. It was declared that "the national status report produced by the Swedish Civil Contingencies Agency...points to major strains on several vital public services" (Government Offices of Sweden, 2015b). Based on this information, the Prime Minister and the minister of the Green Party, literary in tears, proclaimed that "Sweden is in need of breathing space". The metaphor of "breathing space" has received much criticism as a profoundly cynical way of describing the situation, considering that migrants were fleeing terror and sadistic killings, as well as defying the high probability of drowning while crossing the Mediterranean Sea.

The decision was a devastating blow to the mobilisation of civil society in support of migrants, as well as to the general spirit of Sweden as a country that would stand out and serve as an exception to the coldhearted nationalist and xenophobic mentality sweeping through Europe. It exposed the image of Sweden as a secure, modern, and gender-equal country to what Lauren Berlant (2011) has described as the "cruel optimism" of being confronted with "the dissolution of objects/scenarios that had once held the space open for the good-life fantasy" (Berlant, 2011, p. 3). The spirit of being able to stand out was exposed as a form of naivety which, for the moment, had to be abandoned, thus taking a "breathing space" in an effort to handle the alarming situation. In line with what Methmann and Rothe (2012) describe, it seems that politicians were positioned as central actors, while at the same time staging as unable to resolve the situation and forced to pass over responsibility to secure the authorities' administrative procedures. Their position as protectors was enhanced through claims of being in a dramatically vulnerable position, expressed as being unable to breathe.

Rather than becoming a blow to the confidence in politicians, especially a government of Social Democrats' ability to resolve the situation, the memory of these events has now become a sign of a vigorous political ability to take charge. The events provide a form of masculinist protectionism, staging politicians as brave defenders who were forced to make difficult and unpopular decisions that may seem or "feel" wrong by the "naïve" general public. In one of the posters presented to be used for the election 2018, the Social Democrats stated that "We take charge of Sweden's security-The Swedish model 
shall be developed, not dismantled". The text was illustrated with an image of border police officers on a train engaged in checking the identity papers of the passengers, thus carrying out the demand of stopping migrants at the border.

\section{The People's Home Becoming Unfamiliar}

The events of autumn 2015 brought an escalating awareness that the influence of international security forums and policies of the EU-such as the Dublin regulation and Schengen agreement that would supposedly guard against violations of human rights and the surge for totalitarian political regimes-was deteriorating. This was not a specifically Swedish phenomenon. But in the Swedish case, the demands on re-imagining politics, the EU, and international relations must also be viewed in relation to the national idealism of imagining Sweden as a role model of a modern and gender-equal society, where the state guarantees the wealth of the population. The "people's home" became violently unfamiliar and this intrigued the surge for restoration and manifestation that this "home" was still there, somewhere. It just needed to catch its breath for a while.

In her ground-breaking work on ghosts and haunting, Avery Gordon (2008) argues that we need concepts and theoretical models that describe the power that is manifested as a form of present absence, as for instance in events when we become aware of or are unable to disregard that something is missing. The things or people that are not present can become a dramatic presence due to their absence and the very fact of their nonattendance can have a powerful influence on social relations. In the second edition to the book, Gordon states that her project may have seemed obscure in the 1990's, but that the elaborations made much more sense in relation to the aftermath of the September 11 attacks and the global war on terror. At this point, the figure of ghosts was evoked as a means of warfare, such as in the cases of "ghost-airplanes, ghost prisons, ghost 'detainees'" (Gordon, 2008, p. xix). The theoretical elaboration on hauntings and ghostly matters help to explain elementary aspects of how securitisation evokes a form of liminal space or state of exception. In relation to the subject of this article, the term haunting can help to conceptualise the lingering anxiety arising as the self-acclaimed feminist Swedish government would not only challenge the image of Sweden as an exception, but also use this image so as to make claims that closing the borders for migrants was the only way to secure the traditional "Swedish model" of a modern and gender-equal society. This ideal of Sweden evolved as a powerfully haunting image, in line with what Gordon describes as those "instances when home becomes unfamiliar when your bearings on the world lose direction" (Gordon, 2008, p. xvi).

In the Swedish context, the refugee situation became specifically haunting since it did not just consider the legitimacy of the EU or international infrastructures such as the UN, but also challenged the idealisation of Sweden as a role model when it comes to social and gender-equal policies. It exposed the self-conception of Sweden as a nation that "carries solidarity as our greatest character" as a castle in the air. But rather than doing away with this idealism, it seems that there are many efforts to rework the notion of solidarity so as to declare that, in fact, the idealism was defended. To do this, some forms of lives were rendered unaccountable or, following Butler (2004), ungrievable. The idealisation of Sweden as the most secure, modern, and gender-equal country in the world adheres to a form of necropolitics, forcing citizens to develop their ability to grieve the lives of those who contribute to the welfare system (by working, consuming, paying taxes, and living according to gender-equal values) while at the same time developing the ability to stay cold-hearted in relation to those others who are positioned as tearing or plaguing the system.

In the aftermath of the acute events during the autumn of 2015, the Swedish government has intensified the search for migrants who refuse to leave the country after having their application for asylum rejected by the Swedish Migrations Agency. This situation has especially escalated as a consequence of the terror attack in Stockholm on April 9 2017. The man driving the truck down a pedestrian street in central Stockholm, killing five people, was positioned as an illegal migrant who remained in the country after his application for asylum had been rejected. The Prime Minister has stated that in an effort to prevent these types of attacks in the future, more forceful routines of deportation and policing of migrants was required as a continuation and reassurance of the government's orientation of being tough on migration (Government Offices of Sweden, 2017).

\section{Conclusions}

In this article, I have touched upon the conflicting ways in which the idealisation of Sweden as a modern and gender-equal country was articulated as a focal point in the establishment of threat and crisis narratives in relation to the dramatic events of the refugee crisis in 2015. Sweden's association with gender equality and a modern welfare state was positioned as a trait to be powerfully defended, but also as a form of weakness that made the society vulnerable to threats. First of all, when the Swedish government was forced to adjust to the recent years' political orientation of antiterrorism and restrictive immigration policies, it required that Swedish exceptionalism be reformulated as constituting a form of naivety, by claims that this was not the time for idealism but rather a realist approach. The statement on being naïve expressed that the ideals of the "people's home", with its values on solidarity and gender equality, had to be abandoned in an effort to hold on to the prophecy of regaining its former glory in the future. At the same time, it silenced that the welfare state system had been dismantled by the neoliberal reforms that have 
dominated Social Democratic politics since the 1990's (Mulinari, 2016; Scarpa \& Schierup, 2018).

Second, staging a nation, in this case Sweden, as having been naïve, effectively changed the legitimate reference object of the welfare state from vulnerable people to the authorities' vulnerability and urgency of regaining control. Thereby, authorities were able to make claims on legitimacy which they would not otherwise have been able to make. Citizens were asked to trust the authorities and not directly engage with vulnerable groups, thus depoliticising conducts and routines by the authorities that entailed racial profiling and violations of human rights. It also drew attention to increased demands on authorities to be more determined in taking actions against migrants that had had their asylum application rejected. At the same time, NGO's and activists that support migrants where positioned as a security threat. The issue is then no longer the abandonment of Swedish exceptionalism, but rather how Swedish exceptionalism was reclaimed through securitisation. As I have argued, one expression of this was how the Social Democrats used securitisation in the promotion for the election in 2018. In these processes, vulnerable groups who were not able to "manage their risks" were positioned as tearing on the "system" and rendered ungrievable.

In The Cultural Politics of Emotions (2004), Sarah Ahmed asks: "How does a nation come to be imagined as having a 'soft touch'?" She takes the example of rightwing nationalist rhetoric where politicians are stated to have failed to protect the nation by becoming soft on policies regarding immigration, equality, and egalitarianism. The target of this rhetoric was the so-called "political correctness" that had supposedly made the nation vulnerable and open to being "injured by these others, who are taking what is yours" (Ahmed, 2004, p. 1). This way of ascribing a soft skin to the nation, and the looming apocalyptic gaze that it performs, is very similar to the manner in which securitisation discourses were circulating in the Swedish context. But it does not just concern the form of blatant xenophobia that Ahmed describes, where the "others" were portrayed as robbing or swamping the nation. Rather, it could also entail a banal and lingering sense of loss. In the Swedish case, this connects to a form of confrontation with the present absence of the modern, secure, and gender-equal society, which paves way for a general surge of, or incitement for, political narratives that promise to be able to regain Swedish exceptionalism. As I have suggested in this article, this promise may enforce a "culture of danger" and securitisation that further extends the political hegemony of neoliberal reforms as well as the disciplining mechanism of masculinist protectionism that demands citizens to subject to the protectors' superior authority and accept a passive position as grateful dependants. The surge for reassuring Swedish exceptionalism merges with securitisation, suggesting that citizenship is exclusive for those who "do well" while vulnerable groups, as well as political activism, become associated with security threats.
In this case, the articulation of Swedish exceptionalism, in the establishment of threat and crisis narratives, may prove counterproductive and rather reproduce and increase social inequality and polarisation.

\section{Acknowledgements}

The research presented in this article builds on the research project Power and Norms in the Work with Achieving Direction and Collaboration During Crisis (MaNISK) funded by the Swedish Contingency Agency from 2017-2022.

\section{Conflict of Interests}

The author declares no conflict of interests

\section{References}

Agamben, G. (2005). State of exception. Chicago: University of Chicago Press.

Ahmed, S. (2004). The cultural politics of emotion. Edinburgh: Edinburgh University Press.

Balzacq, T. (2011). Securitization theory: How security problems emerge and dissolve. New York: Routledge.

Berg, E. (2015). Systemkollapsen som aldrig fans [The system collapse that never existed]. Flamman. Retrieved from http://flamman.se/a/systemkollapsensom-aldrig-fanns

Berlant, L. G. (2011). Cruel optimism. Durham: Duke University Press.

Brown, P., \& Calnan, M. (2010). The risks of managing uncertainty: The limitations of governance and choice, and the potential for trust. Social Policy and Society, $9(01), 13-24$.

Butler, J. (2004). Precarious life: The powers of mourning and violence. London: Verso.

Buzan, B., Wæver, O., \& de Wilde, J. (1998). Security: A new framework for analysis. Boulder, CO: Lynne Rienner.

Carroll, H. (2011). Affirmative reaction: New formations of white masculinity. Durham: Duke University Press.

Cox, R. (2004). The path-dependency of an idea: Why Scandinavian welfare states remain distinct. Social Policy \& Administration, 38(2), 204-219.

de los Reyes, P., Molina, I., \& Mulinari, D. (2002). Maktens (o)lika förklädnader. Kön, klass \& etnicitet $i$ det postkoloniala Sverige [The different disguises of power: Gender, class and ethnicity in post-colonial Sweden]. Stockholm: Atlas.

Enloe, C. H. (1990). Bananas, beaches and bases: Making feminist sense of international politics. London: University of California Press.

Ericson, M. (2014). Firefighters as exceptional: Heroism, nationalism and masculinity in times of suburban riots and anti-racist protests. NORMA: International Journal for Masculinity Studies, 9(3), 178-190.

Ericson, M. (2017a). Krisberedskapspusslet: Meningsska- 
pande och strategier i arbetet med risk och sårbarhetsanalyser [Crisis preparednes puzzles: Constructing meaning and strategies in the work with risk and vulnerability analyses]. Arbetsmarknad \& Arbetsliv, 23(4), 62-78.

Ericson, M. (2017b). Gendering risk and vulnerability: Challenging masculinity construction in crisis preparedness work in Sweden. Manuscript submitted for publication.

Foucault, M. (2008). The birth of biopolitics: Lectures at the Collége de France, 1978-1979. Basingstoke: Palgrave Macmillan.

Gilson, E. C. (2014). The ethics of vulnerability a feminist analysis of social life and practice. New York: Routledge.

Gordon, A. (2008). Ghostly matters: Haunting and the sociological imagination. Minneapolis: University of Minnesota Press.

Government Offices of Sweden. (2015a). Tal av statsminister Stefan Löfven vid manifestationen för flyktingar [Speach by Prime Minister Stefan Löfven at manifestation in support of refugees]. Retrieved from http:// www.regeringen.se/tal/2015/09/tal-av-stefan-lofven -vid-manifestationen-for-flyktingar-den-5-september

Government Offices of Sweden. (2015b) Government decides to temporarily reintroduce internal border controls. Retrieved from http://www.government.se/ articles/2015/11/government-decides-to-temporarily -reintroduce-internal-border-controls

Government Offices of Sweden. (2017). Effektivare återvändande och motverkande av missbruk av resehandlingar [Efficient returns and combating the misuse of travel documents]. Retrieved from http://www. regeringen.se/pressmeddelanden/2017/11/effektiva re-atervandande-och-motverkande-av-missbruk-avresehandlingar

Habel, Y. (2012). Challenging Swedish exceptionalism? Teaching while Black. In K. Freeman \& E. Johnson (Eds.), Education in the black diaspora: Perspectives, challenges and prospects (pp. 99-122). New York, NY: Routledge.

Hochschild, A. R. (2016). Strangers in their own land: Anger and mourning on the American right. New York: The New Press.

Hood, C., Rothstein, H., \& Baldwin, R. (2001). The government of risk: Understanding risk regulation regimes. Oxford: Oxford University Press.

Kärrman, J. (2015). Löfven: Sverige har varit naivt [Löfven: Sweden has been naïve]. Dagens Nyheter. Retrieved from: https://www.dn.se/nyheter/sverige/lofvensverige-har-varit-naivt

Martinsson, L., Griffin, G., \& Giritli Nygren, K. (2016). Challenging the myth of gender equality in Sweden. Bristol: Policy Press.

Methmann, C., \& Rothe, D. (2012). Politics for the day after tomorrow: The logic of apocalypse in global climate politics. Security Dialogue, 43(4), 323-344.
Mirowski, P. (2013). Never let a serious crisis go to waste: How neoliberalism survived the financial meltdown. London: Verso.

Mulinari, D. (2016). Gender equality under threat? Exploring the dilemmas of an ethno-nationalist political party. In L. Martinsson, G. Griffin, \& K. Nygren Giritli (Eds.), Challenging the myth of gender equality in Sweden (pp. 137-162). Bristol: Policy Press.

MSB. (2015). MSB-analytiker: Ingen systemkollaps [Analyst at the MSB: No system collapse]. Retrieved from: https://blogg.msb.se/krisinformation/2015/12/11/ msb-analytiker-ingen-systemkollaps

Neocleous, M. (2008). Critique of security. Edinburgh: Edinburgh University Press.

Neocleous, M. (2010). War as peace, peace as pacification. Radical Philosophy, 159, 8-17.

Power, M. (1999). The audit society: Rituals of verification. Oxford: Oxford University Press.

Power, M. (2004). The risk management of everything: Rethinking the politics of uncertainty. London: Demos.

Puar, J. K. (2007). Terrorist assemblages: Homonationalism in queer times. Durham: Duke University Press.

Reimers, E., \& Martinsson, L. (2017). Education and political subjectivities in neoliberal times and places: Emergences of norms and possibilities. London: Routledge.

Rogberg, S. (2016). RFSU: Ge ensamkommande sexualkurs [RFSU: Provide unaccompanied refugees with sexual course]. Dagens Nyheter. Retrieved from https://www.dn.se/nyheter/sverige/rfsu-geensamkommande-sexualkurs

Rothstein, H., Huber, M., \& Gaskell, G. (2006). A theory of risk colonization: The spiralling regulatory logics of societal and institutional risk. Economy and Society, 35(1), 91-112.

Scarpa, S., \& Schierup, C.-U. (2018). Who undermines the welfare state? Austerity-dogmatism and the Uturn in Swedish asylum policy. Social Inclusion, 6(1), 199-207.

Schierup, C.-U., \& Ålund, A. (2011). The end of Swedish exceptionalism? Citizenship, neoliberalism and the politics of exclusion. Race \& Class, 53(1), 45-64.

Stiehm, J. H. (1982). The protected, the protector, the defender. Women's Studies International Forum, 5(3/4), 367-376.

Stiernstedt, J. (2016). Regnér: Nyanlända unga ska utbildas i jämställdhet [Newly arrived young people shall be educated in gender equality]. Svenska Dagbladet. Retrieved from https://www.svd.se/regnernyanlanda-vuxna-ska-utbildas-i-jamstalldhet

Virilio, P. (2012). The administration of fear. Los Angeles: Semiotext(e).

Young, I. M. (2003). The logic of masculinist protection: Reflections on the current security state. Signs: Journal of Women in Culture and Society, 29(1), 1-25. 


\section{About the Author}

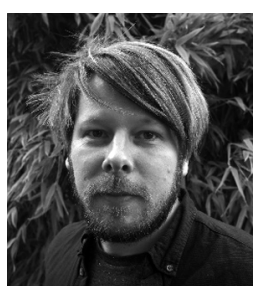

Mathias Ericson is a Senior Researcher at the Department of Cultural Sciences at Gothenburg University. He obtained his PhD from the Department of Sociology at Gothenburg University in 2011. His research interests are masculinity, professions, and risk. He is currently working on a research project that focuses on the relationship between gender-based power asymmetries and crisis management. 